\title{
ON ARENDT, EDUCATION, AND SERVICE-LEARNING
}

\section{Bernardo N. Caslib, Jr. University of the Philippines - Manila, Philippines}

\begin{abstract}
It may be commonplace hearing people accuse the discipline of philosophy of irrelevance, especially when it comes to societal issues. Hannah Arendt, a contemporary political thinker, remarked that philosophy and political action are irreconcilable spheres of thoughtthat the space for contemplation is nowhere near the space for action. Granting Arendt's observation, how can philosophy courses cross the chasm brought about by disciplinal borders? How can philosophy classes help produce active and more engaged citizens? In this paper, I dispute the former claim by way of undertaking two tasks. First, to lay down the groundwork, I provide a philosophical analysis that underlines Hannah Arendt's political position and most important ideas, particularly those that surface in one of her greatest works, "The Human Condition." Second, I point out how Arendt's notions inspire some practices in education and pedagogy, thus paving the way for a genuine application of a philosophical theory to society. By drawing on experiences in teaching philosophy by employing social reconstructionist education and its corollary pedagogical tool, service-learning, this paper hopes to bring back some space to a reconsideration of philosophy as a relevant discipline in society, particularly in education. In the end, I conclude that philosophy and action, contrary to the claim of Arendt herself, are fully compatible. In doing philosophy, the germ of genuine action may be found.
\end{abstract}

\section{INTRODUCTION}

Moans about philosophy being an extraneous "ivory-tower" endeavor that only hair-splitting intellectuals benefit from resound. Gutting (2012) expresses the idea bluntly by citing challenges to the "very idea that philosophy has anything relevant to say to non-philosophers." In this country, we have heard a variant of this claim. While not directly addressed to philosophy, the quip was directed to the goods of the mind generally: "baliw na baliw kayo sa research (you go crazy over research) (Aguilar 2020). The senator who declared this made it sound like doing research, exercising the goods of the mind is antithetical to action, to the actual application, and translation of the products of the intellect into actual practical utility. Admittedly, confronting the 
challenge of applicability of philosophical theories and their translation into praxis is still an enigma in the confines of philosophy classrooms. In teaching Plato and Aristotle in philosophy classes, is it possible to truly live up to their hopes in instilling their concepts to readers and seeing these same concepts come to life in students' everyday lives? Will Plato's just state ever be realizable? How will Aristotle's eudaimonia be attainable? Is there any other way to apply these philosophers' theories? In the case of these men and women of the mind, how can their words leave the narrow pages of books into a space for their realization?

In this paper, I contest this unfounded assertion against philosophy by first looking at the philosophical ideas of one contemporary thinker, Hannah Arendt, who herself almost agreed with the former claim. She herself intimated that philosophy is disconnected from action, the site of real-life application. Arendt herself says that philosophy and political action which is construed as the space for action and praxis, are two distinct and seemingly irreconcilable spheres of thought. Arendt $(1958,15)$ laments that the long history of this hostility between action and contemplation (characteristic of philosophy), or "the primacy of contemplation over activity rests on the conviction that no work of human hands can equal in beauty and truth the physical kosmos, which swings in itself in changeless eternity without any interference or assistance from outside, from man or god." She recounts how the world of philosophy has always sided with the art of contemplation as superior to that of action because ultimately, eternity, in all its majesty, can only be beholden in stillness, in contemplation, in doing philosophy and its characteristic task, wonder. Medieval philosophy, the images of monks-philosophers cooped in their libraries or Rene Descartes isolated in his room in 16th century France, cogitating in stillness his own existence come to mind. These thinkers' lives have always been hailed by philosophy as the acme of existence because of their exercise of the cogitative faculty or reason, not because of their participation in concrete actions, political or otherwise. One of the leading commentators of Arendt, Karin Fry $(2009,5)$, describes this seeming bifurcation as the "...tension between philosophy and politics", between contemplation and action, between philosophy and real-life application. Action has always been consigned to anti-contemplation, as a disruption to a stillness that is required by contemplation, as inferior to the activity that is more god-like: philosophy and wonder.

By engaging and highlighting Arendt's political position and most important ideas, specifically those that surface in her work "The Human Condition" (1958), I demonstrate how contrary to her personal position; her philosophical theorizing has yielded for us a concrete instance of how philosophy can translate into a space for action and praxis - in this case, in the field of education and the classroom. While Arendt positions herself for action against contemplation, this paper will establish that contemplation, in this case, her own contemplation, can yield action in the long run and that, ultimately, the tension that is seemingly found between contemplation and action need not necessarily exist that contemplation may ultimately give rise to genuine action.

Taking into consideration the adaptability of Arendt's views in the Philippine context, I take as a possible guide the views that she forwards in the same work. How are central concepts in Arendt like plurality, freedom, and action, among others, realizable in contemporary times? Education seems to be the most promising response, 
and the classroom appears to be the most palpable space. Suppose Arendt's intimation that philosophy and action are incompatible, how can philosophy classes, or any class for that matter, cross the chasm brought about by disciplinal borders? Do the fruits of contemplation really have to stay within their confines and never reach actual application? With the absence of history-turning events (i.e., holocaust) that Arendt experienced, can students of today, in an arguably, culturally and historically different milieu, come to terms with Arendt's thoughts? It has been contended $(2009,4)$ that Arendt herself "believed that thinking was inspired by personal experience." How can students of the present-day assimilate Arendt's proposals into their lives without similar potent, personal experiences? How can educational institutions create active citizens who are aware of plurality, of the complexity yet beauty of differing opinions? How can universities avoid producing totalitarians and individual zombies who will just submit to the former? I argue that Arendt's personal opinion against philosophy and the life of contemplation may be proven wrong by showing that her own theorizing, the fruits of her own contemplation, are translatable into action through successful assimilation of the social reconstructionist philosophy of education and its consequent pedagogical tool, service-learning in philosophy classes. Contemplation and philosophical musings within the precincts of classrooms may translate into action by introducing service-learning in educators' pedagogy. This is one of the more effective ways by which contemplation and action may be made compatible.

Towards the end of this paper, then and after successfully elaborating Arendt's relevant concepts in her work 'The Human Condition' (1958), the concept of service-learning is interrogated. What is this service-learning? How can servicelearning be of utility to the transmission of philosophical concepts? Conflating Hannah Arendt's ideas and philosophy of education then, this paper intends to shed light on a practical import of the thoughts of the contemporary political thinker. In successfully undertaking this, it is hoped that Arendt's own ideas are shown to be truly translatable into concrete action, and in doing so, Hannah Arendt's reservations with the goods of the mind are proven wrong that the life of the contemplation, Hannah Arendt's own life of contemplation may generate a life of action.

\section{ARENDT AND HER POLITICAL PROJECT}

Arendt published the book "The Human Condition" in 1958. With the urgency to address the political trauma brought about by the holocaust, the war, and the rise of totalitarianism, Arendt examines what made humanity allow these dreadful events to just unfold before their very eyes. Fry $(2009,7)$ claims that Arendt's political philosophy "can be understood as a reaction to the rise of totalitarian politics and the inadequacy of traditional philosophical, political theory in handling the diverse views of the people that are necessary for democratic politics." By employing various distinctions to illuminate humanity's various experiences, Arendt aims to reexamine the predominant, seeming static view of politics during her time. She reveals her disappointment at the sheer amount of conformity that allowed the horrors of her time to happen. In this work, Arendt proposes how to deal with differences of opinion and open discussion as a necessary and expedient element of political action. 
Unleashing her dissatisfaction with philosophy, Arendt asserts that while the life of contemplation or vita contemplativa, characteristic of philosophy, understands theory, it certainly fails to comprehend action and politics. Unfortunately, vita activa, the active life, has long been neglected in favor of contemplation. This lording over by the life of contemplation and philosophy, for Arendt, resulted in a misunderstanding of the concept of action in society and, historically, in grave abuses by a number of people, particularly totalitarians. Misapprehension of the concept of politics by ancient and medieval thinkers down to the enlightenment political thinkers served as an impetus for the mistaken view that philosophy is apart from politics, the site of real action. From Plato down to the French enlightenment and German thinkers, political philosophy has always been characterized by societal models, argumentations of how society and its people should act. Political philosophy has been concerned with blueprint rather than the recognition of the facticity of politics: that it occurs among plural human beings capable of initiating action. For Arendt, all of these products of traditional political philosophy's cogitation and reflection are mistaken. Politics can only be arrived at by actual humans acting and doing according to their own volition. It also did not help that Arendt's life was peppered with historical and societal tragedies, the holocaust included. Surely, Arendt's disappointment with traditional philosophy is also grounded in her own experiences of war and how thinkers were paralyzed in their own ivory-towers while the rest of the world collapsed. To Arendt, it was clear: traditional philosophy is useless in the sphere of politics.

For Hannah Arendt, politics cannot be understood in terms of preconceived ideas of what is right or wrong or what is just and unjust, just like in traditional philosophy. The way out of the labyrinth is to provide an avenue for different people to express their takes and positions on the varying issues of society. The road to what should-be-done can only be reached through politics, where there is consultation among the multitude of people to whom such politics applies. In contrast to attempts at laying down political designs before a consultation, Arendt's stance is to arrive at one after conferring with individuals concerned. Indeed, for her, a virtuous statesman is one who does not live by a blueprint of society and makes sure everything is implemented.

True to her anti-totalitarian stance, Arendt does not promise a certain solution to the perplexities of her day as if she holds it in her own hands. Rather, she $(1958,5)$ intends to examine "human condition from the vantage point of our newest experiences and our most recent fears." As against the preoccupation of most philosophers during and long before her own time, Arendt faces the struggle to look at what people at that time do rather than think. Her concern is not to make a philosophical treatise that offers political prescriptions supported by arguments. Her goal was simple, to understand human experience as it unfolds. The distinctions she makes are all products of her observations of human experiences and preoccupations during her time. She $(1958,5)$ says, "[w] hat I propose, therefore, is very simple: it is nothing more than to think what we are doing." Conscious of the kind of mentality, the kind of learning that individuals had during her time, Arendt proposes a reexamination of man's place in his society, how he acts within his space, and how this current allows for some to abuse and exploit the rest. Plain and simple, she endeavors to examine the human condition. 


\section{ARENDT AND ACTION}

For Arendt, the central and most important political activity is action. There is politics because individual human beings can introduce and engage in actions. Arendt thought there is an imperative to clarify conceptually its distinction from other human activities with which it is confused: labor and work. She divides all forms of activities into three categories: labor, work, and action. According to her, these three are always together and cannot be separated, perpetually parts of a human person's life in a society. Arendt devotes a generous portion of her book to describe each of these three categories and how these three categories shape the way that man lives life in society.

According to Arendt $(1958,96)$, "[t] $]$ he least durable of tangible things are those needed for the life process itself. Their consumption barely survives the act of their production; in the words of Locke, all those 'good things' which are 'really useful to life of man,' to the 'necessity of subsisting,' are 'generally of short duration, such asif they are not consumed by use - will decay and perish by themselves." These things, Arendt, claims are those that are fundamental to human existence and survival. They are consumed just as they are produced. These things that Arendt describes above are the products of labor, the first of the three categories of vita activa. The activity of labor involves nothing but the production of the bare necessities of man, ephemeral entities that must be constantly created because they cease as quickly as they are generated. A farmer who toiled to produce vegetables that will be sold in markets and served on our tables is engaged in the act of labor. The product of a farmer's activity ceases to exist as quickly as it has been produced. Labor, then, with humans engaged in it as animal laborans is not just the proper activity for the political. Labor concerns the requirement of the calls of nature that transpire in the private sphere. Nutrition is a private activity that is necessitated by human beings' existence. Much like animals, humans engage in primitive actions that allow for survival in this form of activity. This is labor.

The second form of activity is work. It involves quite something different from that of labor. As opposed to the fleeting nature of the products of labor, work entails the production of something more permanent. Canovan (1958, IX) recalls that work corresponds "to the artificial world of objects that human beings build upon the earth." Erecting structures, composing songs, and writing a journal article are all forms of work. With it, humans attempt to modify the world according to their suiting. Arendt $(1958,167)$ further asserts that "among the things that give the human artifice the stability without which it could never be a reliable home for men are a number of objects which are strictly without any utility whatsoever and which, moreover, because they are unique, are not exchangeable and therefore defy equalization through a common denominator such as money; if they enter the exchange market, they can only be arbitrarily priced." These are, on the other hand, the products of the homo faber, man as a worker. Unlike the fruits of labor, those of work contain some permanence in them. They are not as easily disposable and can be used and reused. When the animal laborans become homo faber, men enter the phase when he is ready to escape the cyclical demands of existence such as food, allowing for the possibility of political action. In contrast to the animal laborans, the homo faber provides the possibility for public life. Products of fabrication entail an exchange market for goods, a public 
sphere. However, it is still not the ideal space for genuine political action as a market is a place for private interests and barter. It is still not a free space for people acting together for a common good. Thus, just like labor, work does not constitute true a genuine political space.

The last category of human activity for Arendt is action. This is the category that concerns itself with politics and involves humans not out of sheer need like labor or private interests like work, but out of their freedom. In this activity, human beings manifest their being equal with other human beings despite the recognition of difference. This quality, Arendt calls plurality, allows for men to come together for politics. Arendt $(1958,175)$ says that "[h] uman plurality, the basic condition of both action and speech has the twofold character of equality and distinction." Human beings need to be equal because this will allow them to understand each other, even those before or after them. They need to be distinct because otherwise, there would be no need for action or speech to communicate their ideas. Plurality, therefore, is a prerequisite for genuine action. One can find this in a genuine political space where individuals come together, discuss issues where they reveal their individuality with their varying, even sometimes, contrary positions.

Genuine political action is also characterized by natality or the capacity to give birth. Humans can bring something new into the world by offering a contribution to civilization. Man is known by what he speaks and how he acts. Arendt $(1958,179)$ says that "in acting and speaking, men show who they really are, reveal their unique personal identities actively and thus make their appearance in the human world, while their physical identities appear without any activity of their own in the unique shape of the body and sound of the voice." It is only in action where men truly attain their fullest status not as objects but as subjects because of their identities that they reveal and give birth to through action and speech. This, however, is only possible in a space where someone else can recognize who one is. Action, therefore, cannot occur in private but must, all the time, occur in public.

Another characteristic of action is its unpredictability and irreversibility. An action is unpredictable because once one performs an action, one cannot say for certain the degree and magnitude of repercussions the action will have. Fry $(2009,46)$ asserts that action is "inherently unpredictable and unleashes a chain of consequences into a web of human relationships that cannot be entirely constructed in advance." Action is also irreversible because once an action has been committed, there is no way it can be undone. Unlike the products of labor and work that can be destroyed and recreated, the products of actions are final and permanent. It remains in the community if the other members of the community take an interest in it. This can be seen, for example, in how famous speeches of famous world personalities are quoted from time to time and even used as declamation pieces in school or how famous revolutions are still being discussed and celebrated repeatedly.

Arendt's concept of political action is one that can be labeled as anti-totalitarian because it gives a premium to the innate differences among men and how this plurality can give rise to freedom. In Arendt's political perspective, power is not wielded by one person, group, or institution alone. Rather, power is a product of a plurality of individuals acting together and discussing matters of common interest. For Arendt, 
politics should be understood in this manner: that while distinctions can be made, concepts can be qualified, true movement in the society cannot be predicted because this movement is a product of a plurality of individuals whose capacity for action cannot be predicted. The intermingling of this plurality of human beings and the arena upon which this intersection may occur is what, for Arendt, true politics, something that cannot be known using the intellect alone, but something that can only be known by beholding what actually happens and participating where the action occurs.

\section{THE NEED TO BRIDGE CONCEPTS TO ACTIONS}

While Arendt herself is not convinced in the potential of the life of the mind and contemplation to affect any genuine change, her thoughts themselves seemed to invite a lot of curious attempts to understand and to truly engage in what she calls action. While she discouraged to call her own work philosophy, the product of her own contemplation has provoked a lot of discussions and thoughts and certainly prompts for action. Conovan (1956, XVI) recalls that during the students' movement of the 1960s in the United States, her book, The Human Condition, was "hailed as a textbook of participatory democracy."

However, aside from these few episodes of Arendtian successes in translating philosophy into action or, in her words, vita contemplativa into vita activa, how can Arendt's ideal of a plurality of men coming together to determine societal direction be attained in a society that raises men to follow orders rather than speak out opinions? Can classes such as philosophy live up to the expectations that Arendt's view promotes?

In many educational institutions, philosophy is seen as dabbling with mere abstraction. Leder $(2009,81)$ posits that "[p]hilosophy is often thought of as a discipline preoccupied with abstruse and abstract ideals, and therefore disconnected from the 'real world'." Not far from what Hannah Arendt notes, philosophy, even political philosophy, is filled not with action or any chance to get into action, but in most cases, intellectual exercises. Vita contemplativa is alive and pulsating in the discipline, but the vita activa, true political action, is nowhere to be found. Is Hannah Arendt correct in her repugnance of philosophy? Is there no way for philosophy to contribute to political action?

One philosophy of education that shares Hannah Arendt's hope to wake up people's consciousness from their inactive states is social reconstructionism. Gutek (1997, 316) postulates that social reconstructionist educators "see the schools as centers in which teachers and students grapple with society's pressing issues, not merely for academic inquiry but to engage in action-oriented research and solution." By actively immersing themselves in the problems, issues, and most important societal happenings, students are empowered to share in the process of determining the good for society. By initiating them into the process of shared decision-making, planning, and analysis, students are exposed to Arendt's ideal of plurality, action, and freedom. By exposing students to a space for discussion, facing ideas other than their own, and exposing themselves vulnerable to competing positions, the Arendtian vision of politics and action is attained. 
In "Philosophical Foundations of Education," Ozmon $(2012,171)$ argues that "reconstructionists believe that education should be directed towards arousing interest in public activism." How is this going to happen, though? What pedagogy is most applicable in exposing students to the issues of their society? What guarantees that classroom teaching translates into action? Social reconstructionists support the idea that allowing students to go out of the school and learn theories in the field are more potent in teaching compared to exposing them to "sterile" books and lectures. Ozmon $(2012,171)$ mentions Benjamin Barbers, who believes that "democracy and education are inextricably intertwined, and that one cannot exist in its fullest sense without the other." By this, he meant that education should be a national priority and education, in turn, should be geared towards growing national consciousness. He promotes servicelearning as the most appropriate way to help students get involved in their community and get primary information, not from books and researches, but from first-hand sources, their community itself.

\section{WHY SERVICE-LEARNING AND WHY ARENDT?}

The forces that propelled service-learning in the United States and Hannah Arendt's theorizing in the 1960s are actually similar with one another, namely, social disconnection and political apathy. This makes service-learning an apt pedagogical strategy to galvanize the kind of politics that Arendt recommends among men.

Current research points to social disconnection as a rampant phenomenon in the United States. In her text, "Great Ideas Using Service-Learning \& Differentiated Instruction to Help Your Students Succeed," Gent $(2009,17)$ found out that compared with earlier generations, Americans now "signed fewer petitions, belonged to fewer organizations that meet face to face on a regular basis, socialized with their friends and families less often, and knew fewer of their neighbors." Additionally, she $(2009,17)$ argues that this kind of disconnection impedes people's ability to communicate with others, to present themselves as fellow men, to discourse important issues, and to "build social capital." Social Capital, according to Gent $(2009,17)$, "is defined as the collective value of features of social networks, norms, and social trust to facilitate working together for mutual benefit." Without a firm and robust social capital, individuals are incapable of coming together and deciding on a community's common good. Without social capital and a steady connection with others, a conversation is impossible, and speech for consensus-building is silenced. Recalling Arendt, she articulates that only in coming together can people express their speech and action. In "Arendt and Heidegger," Villa $(1996,31)$ argues that "genuine political action is nothing other than a certain kind of talk, a variety of conversation or argument about public matters." When individuals are disconnected, no discussion may ensue. The Arendtian view of action is rendered impossible. Disconnection does not allow people to lay down their cards and declare their opinions no matter how different they may be. In a space such as this, political action is not possible, and true to Arendt's assessment, totalitarianism can exist.

Likewise, current research points that political apathy has been seen to be increasing. Few people are interested in politics and political discourses. Gent (2009, 
18) contends that in the United States, people did not aspire to public service, "they were cynical, and they distrusted the political system." People no longer vote as much as before. Discussions with family about politics dwindled. In the Philippines, although anecdotal, the same can be said. Political action and demonstration are noticeably fewer in the city. Although most impositions still meet resistance, the social media has become the new space for political discussion and resistance. The problem with this, however, is the limited amount of people involved in the discussion. Hannah Arendt recommends that all people should be involved in political discussions. Men must speak their minds in a democratic space. But what if the space is not something available to all, just like internet connectivity? What issues will probably sting people, bring them into democratic communities again to discuss? What societal problems will probably move people to do something, wear their thinking caps to see things in a different light?

\section{SERVICE-LEARNING AS A PEDAGOGY}

Given the historical similarity between the beginnings of service-learning pedagogy and the Arendtian project, it seems that Hannah Arendt's philosophy can realize its vision of initiating genuine action by employing service-learning. By enjoining students to participate in service-learning, the aims of Hannah Arendt may be realized, which is to encourage students to learn to work with true political action characterized by working with a plurality of individuals with different approaches and styles yet coming up with a consensus.

In "The Complete Guide to Service Learning," Kaye $(2004,7)$ defines servicelearning "as a teaching method where guided or classroom learning is deepened through service to others in a process that provides structured time for reflection on the service experience and demonstration of the skills and knowledge acquired." What does this mean? This means that to engage in service-learning involves going out of the classroom to "deepen" what has already been taught inside the classroom. Servicelearning involves taking concepts inside the classroom into the real world in direct communion with other people. This communion presents opportunities for students to truly live up to the Arendtian mantra of plurality and natality of action. By engaging in communities, students are given the unique opportunity to learn from another person who may present a different mode of existence foreign to the student. Likewise, students are usually provided with the chance to help and give rise to an initiative to provoke some change in other people's lives.

A class in Asian philosophy, for example, related by Drew Leder, can be set to visit sites that have pre-arrangements with the university: a center for AIDS victims and a home for the indigent, akin to the Home for the Aged Centers that we have in the Philippines. Leder $(2009,83)$ informs that the sites that he chooses are those whose "mission and clients relate closely to many of the topics of the course, including personal identity, self-body relationship, karma, death and reincarnation, suffering and techniques for mastering and transcending it, compassion, interdependency, the caste system, social justice, and social activism." After the exposure, the students are asked to respond to several questions prepared by Leder to connect the classroom lessons with realizations gleaned from the exposure. 
As opposed to volunteerism or community service, service-learning aims at the dual role of going out and helping people out in the community while at the same time enriching topics inside the classroom. Gent $(2009,7)$ reasons that "service-learning is a teaching method mediated and directed by a teacher and thoughtfully and deliberately linked to the curriculum, academic standards, and goals." From the totalitarian design of a normal classroom, where the teacher dispels knowledge among passively imbibing students, a service-learning environment provides a chance for students to come up with their design of activity, implementation, and even evaluation. This activity of giving birth to an idea is what Arendt calls natality.

\section{COMPONENTS OF SERVICE-LEARNING}

It might be instructive to look at the components of a service-learning process. Taken together, a service-learning activity applied in a class brings out the different opportunities for students to live up to the ideal of Arendtian action: they engage in activities outside the school to be immersed in a space where they can truly commune, discuss and even disagree with other people of varying backgrounds and perspectives (plurality) and they are enjoined to initiate projects and service activities which characterize the need to give birth to genuine action (natality and action).

The first component of service-learning is investigating community needs. To commence a service-learning project, the teacher and the students must identify together a community as an object of their service-learning. Working with local community leaders, even government agencies may be necessary for this. The first component is important to point out exactly which needs of the community are unmet and where possible intervention is needed. This process recalls Arendt's reminder that in being political, one must start where he is. As opposed to fantasy-formation, real politics demands that one does not posit an account without going into the field and see what must be done. One cannot simply assume the needs of a community because it is what he thinks is needed by all. Genuine initiation in a community to fully commune with members of a particular community is demanded by Arendtian politics. It is by starting fresh without any preconceived notion can the Arendtian concept of giving birth and "creating something new" (Timmermann Korsgaard, 20202, 249) truly surface.

The second component of service-learning is preparation or learning. Gent $(2009,9)$ simply put "this component ensures that students have the skills, knowledge, or attitudes they need to carry out the service." A visit to a Home for the Aged might involve preparatory training for conversing with elders, to orient students on the sensibilities of the old, and some topics which may not be appropriate to deal with in their visit. In identifying possible questions, the students are made aware that what suits them for conversation topics may not be the same with people of different backgrounds. Thus, students are given their lesson in plurality, that human beings are truly different from one another.

Gent $(2009,10)$ defines the third component, action or service, as "the service activity itself." This is where the actual service comes in. Zakin $(2017,119)$ recalls that "the meaning and purpose of education is to impart an old world to new beings, 
preparing children for "renewing a common world" by establishing an active bond to the past that does not just encumber but enables agency." This agency, the capability to act that initiates students into a world where they are situated, is manifested in engaging and, planning out an activity outside school earlier. In a visit to an AIDS institution, this is the part where students converse with the AIDS victims and form a historical narrative of their lives, for example or profile. In a community teach-in session, this is the part where the students tutor small kids. These may be further divided into several kinds.

Direct service, the first kind, is described by Gent $(2009,10)$ as "putting students in direct contact with the need area." Direct service entails that the students converse with the beneficiaries of the service. This is the part where students develop traction on the ground. By immersing in the lives of their beneficiaries, often different from their own, students get a grip of a different kind of reality, a reality that has insulated them from the real scene. Often, students who stay with another family, usually an indigent, for a week, is presented with another taste of reality, something that might even be unimaginable for some. Direct service allows men, in this case, students, to be able to relate to other people, jumpstarting the entire process of opening up to plurality-something that Hannah Arendt advocates.

Civic or political action is another type of service. Gent $(2009,10)$ describes this as another form of service where "students actively participate in the democratic process by informing authorities about a problem, advocating for a situation to be changed, or working with authorities on solving a problem." Among the three types of service, this one is the most compatible with Arendt's politics. Lobbying for a cause or writing to a newspaper editor may be examples of this kind of service. Unlike direct service, this type does not just require students to listen to their beneficiaries with the 'pores of their being.' Rather, this might require students to handle diverse views of people that are necessary for democratic politics. Before one can initiate lobbying in a city council, for example, one must first understand the issues of the concerned community. One must get the stakeholders to hold a dialogue, making possible a real conversation. Of course, one may always start small. Engaging locals of a community to talk about their common concerns, a discourse without fear of being judged or maligned, might be enough to spark political action. Hannah Arendt would have agreed.

The fourth component of service-learning is reflection. Although reflection is supposed to be part of every step of the way, reflection after the activity is of premium because it solidifies what students learned from their service-learning. Gent $(2009,10)$ defines reflection as involving "actively, persistently, and carefully considering the action." Reflection makes students understand the significance of their actions, sorts out what they learned, and allows for critical examination of the problems they encountered and possibly better solutions than the ones they offered. Reflection also allows students the chance to understand how others feel, think, and act. This skill is typically necessary for building a democratic politics for Hannah Arendt. The capacity to relate to more people and to view things from the spectacles of others is a requisite in a truly political space.

Service-learning presents a total opportunity for students to live up to the Arendtian political philosophy of action. As opposed to normal classroom sessions 
that only stimulate the mind, or the vita contemplativa of the students, service-learning affords an opportunity for students to leave the narrow confines of their classrooms and books to engage with other human beings, often different from them. This learning opportunity exposes students to a chance to dialogue on issues of relevance in society. With a divergent background from students, individuals from communities usually offer students the unique opportunity to recognize what Arendt calls plurality. By reminding students that multiple other perspectives and conditions exist, servicelearning solidifies the notion of plurality. By showing students that different individuals may hold different views, the learning opportunity also addresses the need for students to recognize freedom, freedom to hold one's own views, and initiate one's own action. In the end, service-learning also invites students to reflect on action points. What are they to do after the exposure that they have obtained in communities? What action may they initiate? Even policy papers that they can come up with their classmates after succeeding discussions qualify as part of genuine Arendtian action. Service-learning, then, realizes the aims of Arendtian philosophy. It translates into action what Arendt never hoped philosophy and the life of the mind could do: to instigate action.

\section{FINAL REMARKS AND CONCLUSION}

In Bradshaw's $(1989,3)$ introduction to her book "Acting and Thinking," she says that the main theme of The Human Condition can be recapitulated in this manner: "action and speech are the supreme expressions of civilization, for they reveal plurality and freedom as constitutive elements of a distinctly human existence." Human existence can only be truly realized if there is recognition of each other's differences, individuality, and humanity's plurality. That humans cannot be encapsulated into a particular mode and expected to act in a certain way is surely the most palpable manifestation of freedom. Only in initiated actions and speech by individuals will these be realized. Combating the dwarfing effects of vita contemplativa and its long-held power in the history of thought, Arendt insists on the vita activa as the ideal emphasis of human affairs. Action and speech, not thought, form the backbone of human existence. By allowing oneself to partake in freedom and plurality, man can attain his fullness, for these two, present in action, are the only things that differentiate men distinctly from animals. Indeed, D'entreves $(1994,67)$ puts it as only "by acting we preserve the world of human affairs from the corruption and decay it would be subject to were it left to the automatism of natural processes." It is in action that we manifest genuine freedom, and it is only in the practice of freedom where we can truly initiate an action.

Humans can only find genuine meaning in the world if this understanding is shared with other people - that is, in a political space. D'entreves $(1994,70)$ explains that for Arendt, action is defined as well in plurality because plurality "confirms the reality of the actor and his or her deeds - and creates the condition for remembrancesince through the telling of (plural) narratives deeds can be made to outlast the life of the doer." Without other humans witnessing a genuine action and manifestation of freedom, speech, for example, an action amount to nothing. Plurality assumes that 
although humans are all the same, species-wise, and thus assures understanding of each other's plight and status, each is still a different entity, with a unique perspective and view of the world.

How can these thoughts translate into action? In the contemporary scene, the most potent mode seems to be that suggested by the social reconstructionist educators. The social reconstructionist's aim to educate students so they can change society by exposing them to real-life situations and education is the most compatible pedagogical bent to Arendt's thoughts. Social reconstructionism employs service-learning as an educational method. By allowing students to launch their own projects, with the teacher as a guide, to serve their community, students actualize Arendt's ideals such as action, freedom, and plurality. By initiating, giving birth to an action in specific communities, students are made to understand what change, what difference they can make in society. By giving students a chance to see the world differently, from a perspective that's not just theirs, but of a community, a group of people who discuss, students begin to comprehend plurality and the innate difference among mendiversity in unity.

In the end, the initial problem raised in this paper has been resolved. With Arendt agreeing with a devastatingly familiar idea that philosophy, representing the life of contemplation on the one hand, and practice and application, representing action on the other, are incompatible and independent of one another, this paper systematically argued to the contrary. Arendt's impression is that contemplation (philosophy) and action (practice) are incompatible. However, if contemplation and action are incompatible, they cannot come together and be related to one another. It has been shown that Arendt's philosophy inspires service-learning and that servicelearning, in turn, inspires action. Given this, it logically follows that Arendt's philosophy inspires action. Therefore, if philosophy inspires action, then contemplation (philosophy) and action (practice) are not incompatible. Surely, they go hand in hand. Arendt may have her qualms with philosophy's potential to effect change, but her own brand of philosophizing has spawned not just conversations and discourses but tons of prompts for genuine action. Arendt should be pleased, having been proven wrong.

\section{REFERENCES}

Aguilar, Krissy. Villar hits DA for High Budget on Corn Research: 'Baliw na baliw

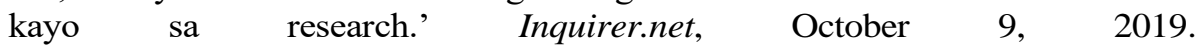
https://newsinfo.inquirer.net/1175450/villar-hits-da-for-high-budget-on-cornresearch-baliw-na- baliw-kayo-sa-research. Accessed: December 3, 2021.

Arendt, Hannah. 1958. The human condition. Chicago: The University of Chicago Press.

Brandshaw, Leah. 1989. Acting and thinking: The political thought of Hannah Arendt. Toronto: University of Toronto Press.

Conovan, Margaret. 1958. Introduction. The human condition. Chicago: The University of Chicago Press. 
D'entreves, Maurizio Passerin. 1994. The political philosophy of Hannah Arendt. London: Routledge.

Fry, Karin. 2009. Arendt: A guide for the perplexed. London: Continuum International Publishing Group.

Gent, Pamela. 2009. Great ideas using service-learning and differentiated instruction to help your students succeed. Baltimore: Paul H. Brookes Publishing Co.

Gutek, Gerald. 1997. Philosophical and ideological perspectives on education. MA: Alylyn and Bacon.

Guting, Gary. 2012. Philosophy — What's the Use. The New York Times, January 25, 2012.

Kaye, Cathryn Berger. 2004. The complete guide to service-learning. Minneapolis: Free Spirit Publishing.

Leder, Drew. 2009. Escaping the cave: Experiential learning in the classroom, community and correctional institutions. In Teaching Philosophy. Edited by Andrea Kenkmann. London: Continuum International Publishing Group.

Ozmon, Howard. 2012. Philosophical foundations of education. New Jersey: Pearson Education, Inc.

Timmermann Korsgaard, Morten. 2020. Visiting examplars: An Arendtian exploration of educational judgment. Ethics and Education. 15(2): 247-259.

Villa, Dana. 1996. Arendt and Heidegger: The fate of the political. Princeton: Princeton University Press. 